of course, an exact chronological sequence, but a combination of that idea with the priority of the events recorded after the method of my Chronological New Testament. The absence of John's Gospel in this list so far is noteworthy and the early date given to Galatians. With these exceptions and the absence of James as yet the order is the same as in my New Testament mentioned above. There is all the usual German thoroughness and care in the details.

A. T. Robertson.

DER TEXT DES NFUEN TESTAMENTS. Neue Fragen, Funde und Forschungen der Neutestamentlichen Textkritik.

Von Lic. Rudoif Knopf. A. O. Professor der Theologle a. d. Univ. Marburg. Verlag von Alfred Töpelmann, Glessen, Germany. 1906. Pr. M. 1. S. 48.

The Germans are taking fresh interest in Textual Criticism of the New Testament. This book is one of the best recent discussions of the elementary matters concerning the subject. The author is familiar with the new views about the importance of the Western type of text, the new light on the Syrian Versions, the Latin Versions, and the papyri. It is really astonishing how much of real information is packed into 48 pages. No revolutionary suggestions are offered, but that is not looked for in a handbook. The book is a good model for such work, and is useful to others besides beginners,

A. T. Robertson.

\title{
A CRITICAL AND EXEGETICAL COMMENTARY ON THE GOSPEL ACCORDING TO MATTHEW.
}

By Willoughby C. Allen, M.A., Chaplain-Fellow, and Lecturer in Theology and Hebrew, Exeter College, Oxford. Chas. Scribner's Sons, New York. 1907. Price. \$3.00 net. Pages 338.

This very welcome volume has been long desired. Mr. Allen has eminent qualifications for his task because of his mastery of Hebrew and familiarity with the Jewish thought of the first century, A.D. That is essential for one who wishes to write a critical commentary on the Gospel of Matthew. Mr. Allen has given himself rigidly 